\title{
NIEDOCENIONA MITOLOGIA NIEDOCENIONYCH - REFLEKSJE O KRÓLU MRÓWEK ZBIGNIEWA HERBERTA, CZYLI TRAGICZNA PRÓBA OSWOJENIA OKRUCIEŃSTWA BOGÓW
}

Król mrówek ${ }^{1}$ został wydany trzy lata po śmierci Herberta. Podtytuł głosi: Prywatna mitologia. W krótszej, odmiennej wersji zbiór wyszedł w języku angielskim. Herbert przygotowywał szersze polskie wydanie, ale nie zdążył go ukończyć. Ostateczną formę nadał mu wydawca - Ryszard Krynicki. Kwalifikacja genologiczna tekstów składających się na antologię (wcześniej drukowane były w prasie), może sprawić spore trudności. Paweł Czapczyk na przykład nazywa Herbertowskie narracje quasi-esejami lub prozami poetyckimi. Jacek Łukasiewicz z kolei stosuje nazwę "mitologiczne apokryfy” i to chyba ona najlepiej oddaje sens zawartych w zbiorze tekstów - są one osadzone w antycznej tradycji, lecz Herbert traktuje greckie przekazy i archetypowe warianty jako pretekst do zabrania głosu w sprawach aktualnych. Próbuje w tym zbiorze zadawać bardzo istotne pytania z dziedziny filozofii, literatury, etyki, polityki... Nie zawsze udziela na nie odpowiedzi, bo przecież nie na każde pytanie trzeba znaleźć odpowiedź - czasami ważniejsze i bardziej pożyteczne jest samo medytowanie nad problemem. Chodzi mu przede wszystkim o, jak to kiedyś sam nazwał, „opukanie starych idei ludzkości”. Wydaje się, że jest to również zadanie dla odbiorcy, wpisanego w dzieło Herberta zatrzymać się nad dawnymi tekstami, by bardziej zrozumieć siebie

1 Wszystkie cytaty z Króla mrówek przytaczam za wydaniem: Zbigniew Herbert, Król mrówek, pod red. Ryszarda Krynickiego, Kraków 2001. Po zacytowanym fragmencie podaję w nawiasie tytuł utworu oraz numer strony. 
i swoje czasy. Dawność motywów antycznych pozwala na potrzebny dystans, który uwalnia od zbędnych i fałszujących prawdę emocji.

Na gruncie polskim jest to kolejna odsłona mitycznych wyobrażeń starożytnych Greków i Rzymian obok najbardziej znanych: Starożytności bajecznej Tadeusza Zielińskiego, Mitologii Jana Parandowskiego, Mitologii Greków i Rzymian Zygmunta Kubiaka czy mitologii ad usum Delphini - Wandy Markowskiej (Mity Greków i Rzymian) i Ireny Parandowskiej (Ze świata mitów), lub kolejna odsłona mitologii dla „nieco starszych”, jak Mitologia dla dorosłych Stanisława Stabryły i Priapea Jerzego Ciechanowicza. Na polskim rynku wydawniczym ciągle są też obecne mitologie pióra pisarzy obcych, np. Mity greckie Roberta Gravesa czy Mitologia Greków Karla Kerényiego.

Jak można się dowiedzieć z posłowia wydawcy, pierwotnie Herbert zamierzał nadać całości tytuł Atlas. W części opatrzonej przez Krynickiego nazwą Utwory z kręgu «Króla mrówek» (nie dokończone lub zaniechane) znajduje się tekst zatytułowany Wstęp do "Atlasa». Nota autobiograficzna, który potraktować można jako autorskie credo, klucz interpretacyjny do całości zamieszczonych w tej fragmentarycznej mitologii tekstów. Czytamy, że:

Mitologia, jakiej uczono go w szkole, napawała go odrazą, była bowiem tryumfem antropomorficznej bestii

- gromadził skamieliny, odciski pazurów

- nienawidził rasy zwycięzców i jego przymierze z pokonanymi wydawało mu się odziedziczone

po górze, strumieniu, ściganym owadzie i melancholijnym olbrzymie

- cała jego sympatia kierowała się ku

zmęczonym bohaterom i dwuznacznym.

Domyślał [się] piekła nieśmiertelności, płomieni, które nie spalają, pustynnych płaskowyżów, nie kończących [się] inkantacji.

Oni (bogowie)

darzą nas obojętnością szczodrą i bezmyślną, nie rozumiejąc, że czekamy na karę - jak na łaskę

- kochał potwora i skrzywdzonego 
kochał skrzywdzonego

$\rightarrow$ czyż wiedza o potworach nie była dla niego propedeutyką historii?

(Wstęp do «Atlasa». Nota autobiograficzna, s. 115).

Uważna lektura twórczości Herberta i różnorakie możliwości nieraz sprzecznych ze sobą interpretacji nieuchronnie muszą przywieść czytelnika ku kwestii bardzo mało oczywistej, a mianowicie jego stosunku do religii i kwestii boskości tradycyjnych bogów kultury greckiej. Jak słusznie stwierdził Przemysław Czapliński:

Herbert niemal od początku swej twórczości prowadzi dość szczególny pojedynek z bogami. Pojedynek ten zaczyna się chyba dopiero od drugiego tomiku, jako że nieliczne wiersze z debiutanckiej Struny światła zwrócone bezpośrednio do bogów antycznych (Do Apollona, Do Ateny) stanowią poetyckie wyznania o niemożności odzyskania dawnego sacrum [...]. Jeżeli utwory antyczne ze Struny światła wyznaczały biegun niespełnialnej tęsknoty za światem ludzkim, nad którym bogowie sprawują opiekę, to wierszem $U$ wrót doliny Herbert w jednej chwili osiąga biegun przeciwny - biegun lęku².

Wydaje się, że najważniejsze w Królu mrówek jest właśnie pytanie o bogów, półbogów i herosów antycznych, którzy, gdy dobrze im się przyjrzeć, stają się „antropomorficznymi bestiami”, a ich rzekoma boskość wyraża się przede wszystkim w stosowanej przez nich przemocy. Herbert zachowuje się trochę niczym antyczny pisarz Euhemer, autor Świętego Pisma (Hiera anagrafe), od którego imienia pochodzi pojęcie euhemeryzacji, czyli tłumaczenia tego, co rzekomo przekraczające ziemską kondycję człowieka, na całkowicie ludzkie kategorie. Autor ten twierdził, że mity nie są w żadnym wypadku historiami dotyczącymi sfery nadprzyrodzonej, lecz jedynie zapoznaną przez wszystkich historią o zwykłych ludziach. Bogowie greccy byli bowiem jego zdaniem królami, wielkimi co prawda i potężnymi, co jednak nie zmieniało ich faktycznego statusu śmiertelników.

2 Przemysław Czapliński, Ironia mniejsza. Apokryfy mityczne Zbigniewa Herberta, w: Portret z początku wieku. Twórczość Zbigniewa Herberta. Studia, pod red. Wojciecha Ligęzy, przy współudz. Magdaleny Cichej, Lublin 2005, s. 287. 
Herbert poprzez swoją specyficzną lekturę mitologii składa na niej prywatną sygnaturę, kwestionując rzekomą konieczność wyroków losu. W literaturze antycznej podobne zjawisko występowało u pisarza tworzącego w II w. n.e. - Lukiana z Samosat, który demaskował antycznych bogów w swoich dialogach satyrycznych, ukazując ich w nieprzystojnych sytuacjach.

W rozmowie z Renatą Gorczyńską Herbert trochę ironicznie tłumaczył:

A dlaczego tak lubię mitologię grecką? Bo to jest coś pośredniego między Bogiem filozofów a bogiem Platona i bogiem Sokratesa przede wszystkim, który jest już parachrześcijański, z prefiguracją Boga jedynego. A zarazem z tymi całymi historiami łóżkowymi, polowaniami i metamorfozami bogów, w których, mam wrażenie, Grecy epoki oświeconej nie bardzo wierzyli. To była raczej już figura retoryczna. Piszę takie apokryfy, w których bogowie utyskują, że muszą być wieczni. O ile szczęśliwsi są ludzie, którzy mają skończoną drogę od-do ${ }^{3}$.

Słowa poety nie powinny nas jednak w żadnym wypadku zwieść. Herbert nie jest apologetą wizji świata reprezentowanej w mitach. Nie jest też, wydawałoby się, adwokatem diabła, który traktuje mity z przymrużeniem oka, na kształt romansów kuchennych. Nie chce być ornamentatorem. Herbert to odkrywca i oskarżyciel. Stąd też jego zamiłowanie do apokryfów, czyli tego, co niekanoniczne, nieusankcjonowane przez nieodwołalny wyrok, niezastygłe w spetryfikowanym kształcie. Jeszcze raz oddajmy głos poecie:

Apokryf, jako forma literacka, bardzo mnie interesuje. Teksty, przekazy mają pewne luki. Narzucenie sobie jakichś ram rzeczywistości, ram przekazu historycznego i wypełnienie wyobraźnią tego, co jest dozwolone w granicach wyobraźni, daje mi większe poczucie, że to jest coś warte, niż fabuła, której nie potrafię sugestywnie wymyślić. Prawdopodobnie to wynika $\mathrm{z}$ moich zahamowań, może z braków mojej wyobraźni. Muszę to oprzeć na konkretach.

3 Sztuka empatii. Rozmawia Renata Gorczyńska, w: Herbert nieznany. Rozmowy, [zebrał i oprac. do druku Henryk Citko], Warszawa 2008, s. 175. 
[...] posługując się formą historycznego przekazu, łatwiej mi wyłożyć jakąś prawdę czy jakiś niepokój ${ }^{4}$.

Herbert wie, że nader często historię piszą zwycięzcy, wobec czego podejmuje się roli detektywa, tropiącego miejsca, gdzie można odczuć swąd potraktowanych w sposób nieludzki ofiar. Intencją poety jest pokazać mitologiczne historie z perspektywy przegranych, odkłamać to, co dotychczasowe mitologie (na przykład Kubiaka czy Parandowskiego) brały za aksjomat, a mianowicie: nieuchronność, konieczność, definitywność wyroków fatum - wyznaczonego człowiekowi z góry losu, który w sposób nieodwołalny, kategoryczny i aprioryczny decyduje, że Ifigenia musiała zostać złożona w ofierze, że Anteusz musiał zostać zgładzony, a Arachne i Niobe - ukarane za swoją pychę. Herbert powiada: „We wszystkim, co nieodwracalne, jesteśmy skłonni dopatrywać się ingerencji nadprzyrodzonych mocy władających światem. W istocie sprawa da się bez reszty wyjaśnić w kategoriach ludzkich" (Kleomedes, s. 52). Herbert oponuje więc stanowczo przeciw znieruchomiałej konieczności mitu, wybiera i dowartościowuje to, „co głupie w oczach świata [...], co nie jest szlachetnie urodzone według świata i wzgardzone" (1 Kor 1,27-28). Paweł Czapczyk pisał, że:

paradoksalne demaskacje, szydercze obnażenia i antytetyczne zestawienia, pociągające za sobą całą skalę (nie tylko mitologicznych) przewartościowań - należą do arsenału ulubionych chwytów poety i stanowią nierzadko o differentia specifica jego wierszy, próz poetyckich, dramatów, a nawet esejów. Herbert jest twórcą o zbyt żywej, może wręcz ejdetycznej wyobraźni, by zadowalały go zastane schematy fabularne i w konsekwencji - proste, nieironiczne re-narracje ${ }^{5}$.

\footnotetext{
4 Światło na murze. Rozmawia Marek Sołtysik, w: Herbert nieznany. Rozmowy, dz.cyt., s. 115 .

5 Paweł Czapczyk, Mitologia na nowo odczytana. Wokół prozy poetyckiej Zbigniewa Herberta, „Twórczość” 2003, nr 4, s. 62.
} 
Bogowie, bohaterowie pierwszoplanowi mitologii, nieskazitelni herosi, jawią się nieraz w Herbertowskich apokryfach jako dewianci ${ }^{6}$, istoty bezlitosne, bezwzględne, okrutne, nieczułe i mściwe, a czasem po prostu głupie. Herbert nie jest jednak w tej kwestii absolutnym nowatorem. Podobnie bogów przedstawiali już prominentni przedstawiciele ateńskiego oświecenia w V w. p.n.e., na przykład Eurypides. Jego Dionizos, mszczący się bezlitośnie na rodzinie w Bachantkach, ilustruje w sposób paradygmatyczny okrucieństwo bogów: król Teb Penteus umiera straszliwą śmiercią, jego matka - a zarazem zabójczyni Agawe - musi w stanie pełnej świadomości przyprawiającej o zawrót głowy pojąć, jakiego czynu się dopuściła, dziad Kadmos zaś pogodzić się z kompletną destrukcją całej linii rodowej. Ten ostatni prosi Dionizosa o miłosierdzie, ale wyrok boga winnej latorośli jest nieubłagany. Co ważne, brak ludzkiego współczucia i miłosierdzia nie pojawia się dopiero na końcu Bachantek - w przebiegu całej tragedii Dionizos wykazuje całkowity brak zrozumienia dla ludzkiej niedoskonałości, kruchości.

Dlaczego wobec tego Eurypides i inni przedstawiciele ateńskiego oświecenia, na przykład Ksenofanes, krytykujący wizje zawarte w poematach epickich Homera i Hezjoda, postanowili przedstawić bogów jako mściwych i małostkowych? Odpowiedź może leżeć w samej naturze bogów. Tradycyjni bogowie greccy byli antropomorfizowani zarówno jeśli chodzi o wygląd zewnętrzny, jak i przymioty oraz zdolność do przeżywania uczuć. Symultanicznie wyobrażano ich sobie jako personifikacje potężnych sił natury. Zagadnienie antropomorfizmu, począwszy od Homera, przysparzało wielu problemów (zwłaszcza filozofom). Obdarzenie bogów uczuciami i przypisywanie im cnót przejętych od ludzi ułatwia konceptualizację i pobudza wyobraźnię. Bogowie są jednak nieśmiertelni i nie starzeją się oraz pozostają odporni na ludzkie cierpienia. Odporność ta nieodparcie

\footnotetext{
${ }^{6}$ „Bogowie, tytani, herosi, ach, jakże to pasjonująca i bogata galeria różnych dewiacji psychicznych. W ich świecie roi się od monomaniaków, paranoików, melancholików, schizofreników, nie mówiąc już o takich łagodnych odchyleniach, jak alkoholicy czy erotomani" (Atlas, s. 85).
} 
implikuje u bogów brak uczuć i odruchów prawdziwie ludzkich, takich jak odwaga, altruizm, poświęcenie, które to cechy nie mogą być przypisane bytom niemającym nic do stracenia i nieodczuwającym na własnej skórze żadnego braku. Do pewnego stopnia więc małostkowość charakteryzująca bogów to funkcja przynależąca do systemu.

Antropomorfizm nie może jednak tłumaczyć bezlitosności i braku miłosierdzia bogów u Eurypidesa. Są one zrozumiałe w momencie, gdy rozważymy inny aspekt bogów, a mianowicie, że są oni personifikacjami sił natury. Według przekonań Greków natura nie daje się do końca obłaskawić, prośby o miłosierdzie, zanoszone do sił natury, nie mają więc większego sensu. Nie ma tu także miejsca na mesjaniczną denaturalizację bogów i transcendencję absolutu. Werner Jaeger pisał:

Bogowie greccy znajdują się w ś w i e c i e; wywodzą się z Nieba i Ziemi, dwu największych i najwyższych części wszechświata, a spłodzeni są przez potężną moc Erosa, który również należy do świata jako wszechrodząca pierwotna siła. Podlegają już więc temu, co moglibyśmy nazwać prawem naturalnym. Kiedy myśl Hezjoda ustąpi wreszcie miejsca myśleniu prawdziwie filozoficznemu, bóstwa będzie się poszukiwać wewnątrz świata, nie zaś poza nim, jak czyni to teologia judeochrześcijańska, która rozwija się z Księgi Rodzaju?

Agata Bielik-Robson twierdzi, że:

Religijność grecka - i ta opisana przez Nietzschego pod nazwą „religii tragicznej" [...], i ta opisana przez Wernera Jaegera w kategoriach „presokratejskiej teologii naturalnej” - orientuje się na mit: pewną całościową wizję bytu, która właśnie jako zamknięta całość, opatrzona solidnym arche i domkniętym telos, odsłania się jako wewnętrznie przesycona świętością. Max Weber, a za nim Mircea Eliade nazywają ją religijnością sacrum immanentnego; jego znamieniem jest fatalistyczne domknięcie, doskonałość wewnętrznego cyklu, który powtarza się niezmiennie w rytmie świętych powtórzeń: genesis kai phtora, czyli powstawanie i ginięcie, wyznaczające wieczny

7 Werner Jaeger, Teologia wczesnych filozofów greckich, przeł. Jerzy Wocial, przedm. Juliusz Domański, Kraków 2007, s. 47. 
powrót tego samego, niezmienne pulsowanie greckiej physis, której idea fascynuje jeszcze Nietzschego i Heideggera ${ }^{8}$.

Natura bogów to jeden z wielu intelektualnych, religijnych, filozoficznych tematów, nad którymi debatowano w okresie złotego wieku w Atenach. Można się pokusić o stwierdzenie, że Eurypides zupełnie świadomie przekracza granice antropomorfizmu, poszukując sposobu na włączenie swojego głosu do ogólnopaństwowej debaty. Ze zwyczaju traktowania bogów na wzór i podobieństwo człowieka Eurypides wyciąga radykalne wnioski, wywracając na nice tę ideę i doprowadzając ją do absurdu. Zdaje się mówić, że bezrefleksyjne antropomorfizowanie bogów będzie nieuchronnie doprowadzać do powstawania takich „finalnych produktów” jak Dionizos z Bachantek.

Herbert, podobnie jak Eurypides, stroni od fałszywej i ckliwej poetyczności oraz apologii dehumanizującego porządku. Narrator Herbertowskich apokryfów - dysponujący świadomością człowieka, który doświadczył dwóch totalitaryzmów: czerwonego i brunatnego, oraz wrzucony został w porządek komunistyczny wyznaczony przez jałtański triumwirat, człowieka wydziedziczonego z usankcjonowanego porządku sygnowanego szacownym stemplem Homera, starożytnych epików, poetów lirycznych i dramaturgów mitologicznych - zdaje sobie sprawę, że jeżeli odjąć od historii opowiedzianej w micie nimb fatalności i, jak Lévi-Strauss, paradygmatycznie czytać mitologem po mitologemie $^{9}$, ukaże się naszym oczom krwawa miazga mitologii z pasmem mordów, kłamstw, okrucieństw, wiarołomstwa, zaprzaństwa, zemsty i odwetu. Herbert podejmuje jednak mitologiczną tradycję. Czyta ją

\footnotetext{
${ }^{8}$ Agata Bielik-Robson, Powrót mesjańskiej obietnicy, czyli nowoczesność w perspektywie postsekularnej, w: Filozofia. Ogląd, namyst, krytyka?, pod red. Marcina Marii Bogusławskiego, Andrzeja Kucnera i Tomasza Sieczkowskiego, Olsztyn 2010, s. 45 .

9 Ostatnio kwestią obecności mitologemów: labiryntu i smoka, w poezji Herberta zajął się Bogdan Trocha w szkicu Mythopoeiczne aspekty liryki Zbigniewa Herberta, w: Pojęcia kiełkujące z rzeczy. Filozoficzne inspiracje twórczości Zbigniewa Herberta, [red. Józef Maria Ruszar], Kraków 2010, s. 99-137.
} 
wszakże „pod włos”. Dowartościowuje te postacie, którym tradycyjnie opowiedziane historie odmawiały łaski głosu. W Herbertowskiej re-narracji przywraca się im dotychczas zniekształcone ludzkie oblicze.

I tak na przykład w Historii Minotaura Herbert podważa wszystkie dotychczasowe przekazy i wersje mitu, powołując się na nieodczytane do dnia dzisiejszego pismo linearne A. Opowiada, kim tak naprawdę był mitologiczny Minotaur i rekonstruuje rzeczywisty, zdaniem narratora, tok zdarzeń ${ }^{10}$.

Trzeba sobie w tym momencie uświadomić, że w tej, jak i w innych Herbertowskich reinterpretacjach i rekonstrukcjach, poecie nie całkiem chodzi o dotarcie do rzekomo istniejącej struktury, która na poziomie głębokim i bardzo głębokim miałaby sterować porządkiem powierzchniowym, podporządkowując go sobie w sposób całkowity. Herbert nie jest strukturalistycznym majsterkowiczem, dokonującym z nagromadzonych elementów bricolage'u i rekonstruującym hipotetyczny, binarny obraz świata. Nie tworzy więc tak jak strukturaliści ciągów syntagmatycznych składających się z szeregu mitemów i nie grupuje ich w paradygmatyczne wiązki, które jednoczyłyby w sobie w sposób wyczerpujący i rozłączny wszystkie aspekty mitu, by odwołać się do słynnej analizy historii Edypa dokonanej przez Lévi-Straussa. Znakomity francuski etnolog z charakterystyczną dla siebie dezynwolturą (symptomatyczną dla tego typu badań) wyodrębnia w micie cztery wiązki: "przecenione więzi pokrewieństwa”, „niedocenione więzi pokrewieństwa”, zgładzenie potworów, „trudność poruszania się w postawie pionowej", a sam mit odczytuje jako fenomen, mający na celu mediację (przejście, skonstruowanie zwornika, Heglowską syntezę) pomiędzy dwoma skonfliktowanymi ze sobą świadectwami dotyczącymi ludzkiego pochodzenia: przekonaniem o autochtoniczności ludzi (jak utrzymują religioznawcy i etnolodzy,

\footnotetext{
10 „Biedny Minotaur! Miałem dla niego, od zamierzchłego dzieciństwa, więcej czułości niż dla Tezeusza, Dedala czy innych spryciarzy. Kiedy pierwszy raz ojciec opowiadał mi tę bajkę, uczułem bolesny skurcz serca i współczucie dla pół zwierza, pół człowieka, spętanego labiryntem i obcą sobie ludzką historią, pełną podstępów i toporów" (Zbigniew Herbert, Labirynt nad morzem, Warszawa 200o, s. 42).
} 
Grecy byli przeświadczeni o pochodzeniu człowieka z ziemi na podobieństwo roślin; pierwszy człowiek był półwężem) i o ich pochodzeniu ze związku mężczyzny i kobiety. Zagadka Sfinksa i wątpliwości Edypa co do własnego pochodzenia odzwierciedlałyby w paradygmatycznej strukturalnej lekturze rudymentarny problem ludzkiej kondycji: kim jest człowiek i jakie jest jego pochodzenie. Lévi-Strauss tropi zatem w mitologicznych przekazach wszystkie ślady, które mogłyby potwierdzać postawioną przez niego tezę, i odnajduje ślady monstrualnego, ambiwalentnego, autochtonicznego pochodzenia u trzech przedstawicieli rodu: kulawego Labdakosa, niezgrabnego Lajosa i Edypa z przekutymi stopami. Kalectwo miałoby świadczyć o wyłonieniu się tych postaci z ziemi. Istotą mitu jest wobec tego właśnie pośredniczenie pomiędzy sprzecznymi i niedającymi się pogodzić sposobami pojmowania świata: $\mathrm{w}$ tym przypadku teorią o autochtonicznej archeologii człowieka i empirycznym faktem seksualnej reprodukcji. Mit dostarcza logicznego modelu rozwiązania sprzeczności ${ }^{11}$.

Analiza mitologii greckiej przy użyciu metodologii strukturalistycznej ma charakter paradygmatyczny, jest systemową próbą ujęcia całokształtu greckich opowieści i polega na rozbiciu opowieści na opozycyjne względem siebie mitemy, z których następnie konstruuje się poszczególne syntagmy. Uczeń Lévi-Straussa, Edmund Leach, wyodrębnił na przykład z mitologii osiem opowieści ${ }^{12}$, które „obrazują różne permutacje tej samej akcji” i tych samych bohaterów, dramatis personae: „Król,

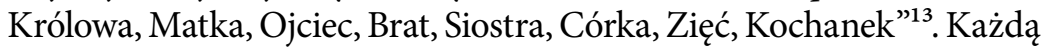
opowieść opatrzył komentarzem. Wśród nich znajduje się również opowieść o Minosie i Minotaurze, potraktowana paralelnie do opowieści o Kadmosie, Europie i zębach smoka. Leach skupia się na „rachowaniu” elementami-wątkami różnych wersji opowieści oraz dokonuje ich strukturalistycznej konwersji i obwersji. I tak na przykład wariant, w którym pojawia się byk, zastąpiony zostaje wariantem $\mathrm{z}$ krową; tam, gdzie raz mamy braci, za drugim razem mamy mężów. Na powierzchnię tych

11 Claude Lévi-Strauss, Antropologia strukturalna, Warszawa 1970, s. 293-296.

12 Edmund Leach, Lévi-Strauss, przeł. Piotr Niklewicz, Warszawa 1998, s. 88.

13 Tamże. 
rekonstrukcji Leach wydobywa opozycje: Zeus (bóg niebios) - Posejdon (bóg morza); dziecko ludzkie - dziecko potwór; Kadmos zabijający potwora - potwór zabijający Minosa (człowieka); Kadmos sam będący potworem - potwór sam będący Minosem.

Redukcja mitologii do cząstek elementarnych, ułożonych następnie w szeregi opozycji tworzących matrycę, którą z kolei nakłada się na mitologiczne narracje, mówi bardzo wiele i o samej mitologii, i o umysłach, które ją wytwarzają - ujawnia mianowicie nierozwiązywalne antynomie zepchnięte do sfery podświadomości zbiorowej i indywidualnej, które wyjawione stoją w sprzeczności z ludzką moralnością i zwiastują nieuchronną ludzką tragedię. Ta metoda jest jednak niezwykle pesymistyczna w swym wydźwięku, sprowadza bowiem ludzi do rzędu pionków w niezbadanej, tajemnej grze struktur, będących w tym przypadku kryptonimem nieodwołalnego wyroku losu. Ofiary składane bogom, stosunki z nimi są pełne ambiwalencji, dwuznaczności, nie obywają się bez przemocy, są okupywane ogromnymi kosztami. Jak słusznie pisze Leach: „nie ma w tych opowieściach bohaterów: są to po prostu opowiadania o nieuniknionej tragedii ludzkiej. Powodem nieszczęścia jest zawsze to, że człowiekowi nie udaje się wypełnić swych obowiązków wobec boga lub krewnego"14.

Oprócz możliwej interpretacji strukturalistycznej pojedynek Tezeusza z Minotaurem oferuje cały wachlarz innych odczytań. Neorytualiści z Cambridge na przykład widzą w nim paradygmat rite de passage, inicjacyjnego rytuału wkraczania młodzieńca w dorosłe życie. Kolejne stopnie przebiegałyby w następujący sposób:

1) Tezeusz przybywający do Aten i mający na sobie damskie ubrania - inicjowany przybywa na miejsce próby jako jeszcze nie w pełni ukształtowany mężczyzna;

2) Tezeusz podróżujący na Kretę - inicjowany udaje się w oddalone od domu miejsce odosobnienia;

3) Tezeusz przeznaczony na zabicie przez potwora sam go zabija inicjowany jest do pewnego stopnia i w pewnym znaczeniu „martwy” poza domem, i często napotyka na swojej drodze potwory;

14 Tamże, s. 99. 
4) Tezeusz spotykający Ariadnę i poślubiający ją - inicjowany jest przygotowany do podjęcia życia seksualnego;

5) Tezeusz powracający do domu i ukoronowany - inicjowany staje się w pełni dojrzały po powrocie $\mathrm{z}$ miejsca próby.

Psychoanalitycy z kolei widzieliby w zamkniętym w labiryncie Minotaurze reprezentację ukrytych, mrocznych, wypartych, niemających dostępu do światła ego pragnień podświadomości: potwór narodzony wskutek seksualnej dewiacji ukryty zostaje w labiryncie, symbolizującym ład ludzkiej kultury wiążącej spętane pożądania. Pojedynek zaś Tezeusza z Minotaurem prowadzi do śmierci Ajgeusza, ojca ateńskiego herosa, co można odczytywać jako echo edypalnego pożądania. Podobnie syn Tezeusza, Hipolit, powtarza wzór kompleksu Edypa, ale tym razem go odwraca: to matka pożąda pasierba i to ojciec doprowadza do śmierci syna.

Reinterpretacja mitu o Minotaurze dokonana przez Herberta polega jednak na czymś zupełnie innym. Według mitologii Minotaur był pół człowiekiem, pół bykiem, odżywiającym się ludzkim mięsem. Herbertowski narrator, wyczulony na fałsz prześladowczych przedstawień, pomija je i wypowiada się o Minotaurze z wielką atencją. Jego zdaniem nie jest on potworem, ale księciem, „autentycznym synem króla Minosa i Pasifae", ergo infantem, delfinem.

Chłopak urodził się zdrowy, lecz z nienormalnie dużą głową - co wróżbiarze poczytywali jako znak przyszłej mądrości. W istocie Minotaur rósł w lata swoje jako silny, nieco melancholijny - matołek.

(Historia Minotaura, s. 90)

Jak pisał René Girard w Koźle ofiarnym:

Monstrualność fizyczna oraz monstrualność moralna nakładają się na siebie w mitach usprawiedliwiających prześladowanie ułomnego. Pojawienie się owego stereotypu w sąsiedztwie innych stereotypów prześladowczych wyklucza wszelkie wątpliwości. Gdyby ta zbieżność występowała bardzo rzadko, można by mieć wątpliwości, jednak zdarza się niezwykle często; jest chlebem powszednim mitologii ${ }^{15}$.

15 René Girard, Kozioł ofiarny, Łódź 1987, s. 41. 
Okazuje się zatem, że Minotaur nie tylko nie jest monstrualną istotą, ale wręcz przeciwnie - to człowiek niedorozwinięty, co jest dla Minosa afrontem i skandalem, ponieważ zagraża autorytetowi władzy: „Król postanowił oddać go do stanu kapłańskiego. Ale kapłani tłumaczyli, że nie mogą przyjąć nienormalnego księcia, bo to mogłoby obniżyć - już i tak nadszarpnięty przez odkrycie koła - autory tet religii” (Historia Minotaura, s. 9o). Minos postanowił przeto, że ściągnie na Kretę „modnego w Grecji inżyniera Dedala, twórcę głośnego kierunku architektury pedagogicznej” (tamże), aby ten wybudował labirynt, miejsce odosobnienia dla Minotaura.

Przez system korytarzy, od najprostszych do coraz bardziej skomplikowanych, różnicę poziomów i schody abstrakcji, [labirynt] miał wdrażać księcia Minotaura w zasady poprawnego myślenia. Snuł się tedy nieszczęsny książę popychany przez preceptorów korytarzami indukcji i dedukcji, nieprzytomnym okiem patrzył na poglądowe freski. Nic z tego nie rozumiał.

(Historia Minotaura, s. 90)

Dedalowy labirynt jest przeto znakomicie opracowaną i skomplikowaną strukturą pedagogiczną. Upośledzonemu księciu towarzyszą tam enigmatyczni preceptorowie. Spostponowany, biedny Minotaur poddany presji myślenia w logicznych ramach indukcji i dedukcji jeszcze bardziej od tych subtelności głupieje. Proces resocjalizacji okazuje się wychowawczym fiaskiem i utopią „szlachetnych” nauczycieli. Skonfundowany Minos zaś, „wyczerpawszy wszystkie środki [...] postanowił pozbyć się zakały rodu. Sprowadził [...] zręcznego mordercę Tezeusza" (Historia Minotaura, s. 90).

Herbertowska historia Minotaura pokazuje proces inicjacji à rebours, prezentując króla jako bezlitosnego i bezwzględnego synobójcę, a z wyzwoliciela Tezeusza czyniąc zwykłego kondotiera i zręcznego asasyna. Minotaur „mądrzeje” w chwili, gdy: „Przez labirynt - niepotrzebny już elementarz - wraca Tezeusz niosąc wielką, krwawą głowę Minotaura o wytrzeszczonych oczach, w których po raz pierwszy kiełkować zaczęła mądrość - jaką zwykło zsyłać doświadczenie" (Historia Minotaura, s. 90). 
Udziałem Minotaura staje się w chwili śmierci to, do czego przez całe jego życie odmawiano mu dostępu: dotykalna rzeczywistość. „Wytrzeszczone oczy” czynią z matołka prawdziwego filozofa, jako że, jak wskazywał Arystoteles, filozofia rodzi się ze zdziwienia... W ostatnim akapicie dochodzi do zmiany czasu narracji z przeszłego na teraźniejszy, przez co historia nabiera „transcendentalnej realności”16. Narrator sytuuje się w ponadhistorycznym i ponadmitycznym porządku, a historia staje się wiecznym Teraz. Przemysław Czapliński nazywa Herbertowską ironię, służącą poecie do przepisywania mitów na nowo, ironią mniejszą, „nie-boską, kontrmityczną albo postmityczną"17. Charakteryzuje ją w następujący sposób:

1) Ironia mniejsza jest rodzajem dywersji uprawianej wobec innych tekstów, ponieważ jej punktem wyjścia są te opowieści (wzorce opowieści), które sankcjonują przemoc jako narzędzie konieczne do utrzymania ładu; ironia mniejsza wkrada się - wślizguje, wnika - do takich narracji, by je podrobić, naśladować i odwrócić;

2) w planie kompozycyjnym ironia mniejsza posługuje się techniką odwrócenia pomniejszającego, czyli odnalezienia perspektywy przynależnej drugoplanowym postaciom bądź elementom; celem takiego działania jest odkrycie prawdy o rzeczywistym przebiegu wydarzeń, prawdziwych motywach działań i prawdziwych skutkach (cel ironii mniejszej zbliża ją do ironii sokratejskiej);

3) w perspektywie etycznej cechą wyróżniającą ironii mniejszej jest stawanie po stronie słabszego - przeciwko przemocy ${ }^{18}$.

Piotr Śliwiński z kolei wskazywał, że dokonana przez Herberta reinterpretacja mitów, rehabilitująca ofiary i dowartościowująca te postacie, które skazane zostały na wieczne milczenie $z$ woli bogów, przeznaczenia, losu, Mojr, wyroczni (któregokolwiek określenia sygnującego rzeczywistość transcendentalną i enigmatyczną tu użyjemy), która tak jak delficka wyrocznia oute legei, oute kryptei, alla semainei (nie oznajmia, ani nie ukrywa, tylko daje znak) - w sposób

\footnotetext{
16 Paweł Czapczyk, Mitologia na nowo odczytana..., dz.cyt., s. 70.

17 Przemysław Czapliński, Ironia mniejsza..., dz.cyt., s. 302.

18 Tamże, s. 302-303.
} 
paradoksalny nie stanowi przewrotu kopernikańskiego w spojrzeniu na mitologię. Autor Króla mrówek, podważając oficjalne narracje i doszukując się w nich szczelin, przemilczeń i pęknięć, wikła się w ten sposób w aporię, od której całą swoją poetyką stara się odcinać w epatowanie oryginalnością. Taka oryginalność, która nagminnie repetuje ten sam wzorzec narracyjny, paradoksalnie przestaje być oryginalna, nurząc swoją monotonnością. Narracja staje się monofoniczna i apodyktyczna, a ironia mniejsza, o której pisał Przemysław Czapliński, okazuje się bronią obosieczną. Podważanie mitu rozumianego jako odwieczne genesis kai phtora (powstawanie i ginięcie), eliadowski cykl wiecznych nawrotów tego samego wpada w podobne, acz nie tożsame, koleiny... Jest to zarzut jedynie częściowo trafny, ponieważ Herbertowi nie chodzi o artystowski, postmodernistyczny retelling, wyciągający na powierzchnię narracji tradycyjne konwencje, wątki i motywy. Herbert faktycznie prowadzi swoistą grę z czytelnikiem, ale nie jest ona zupełnie niefrasobliwa, gdyż autor, pomimo że sięga do rozmaitych wariantów mitu i rozgrywa je w zupełnie współczesnej scenerii oraz posługuje się nieraz znanym $\mathrm{z}$ postmodernistycznej estetyki groteskowym, ludycznym niejako mieszaniem stylów, broni przy tym wyznawanych przez siebie wartości. Jest to zresztą święte prawo autora, który w ten sposób potwierdza, że mimo postępu technicznego, zmiany otoczenia, aktorów oraz instrumentów, które im towarzyszą, pewne postawy ludzkie zachowują swoją uniwersalność.

W Psie infernalnym, zadedykowanym Julii Hartwig i Arturowi Międzyrzeckiemu (adres tej dedykacji rzuca snop światła na rozumienie tekstu, ponieważ w sposób niejako naddany z góry bohaterem utworu czyni słowo), już na początku tekstu narrator pieczołowicie przytacza rozmaite znane mu wersje mitu, powołując się na różnych autorów (Hezjoda, Homera, Pindara, a także na rzeźbiarzy i malarzy greckich). Okazuje się, że historia Heraklesa i Cerbera była od najstarszych czasów opowiadana na rozmaite sposoby: „Wersje są różne i sprzeczne z sobą. Wahają się między krwawymi zapasami, a niemal niedzielną wycieczką myśliwską po łup" (Pies infernalny, s. 20). Sam narrator też opowiada swoją wersję mitu. Zaznacza to zmianą 
formy - do opowiadania wkrada się udramatyzowany zapis - podział na role, gdzieniegdzie opatrzony didaskaliami. Narrator snuje swoją opowieść z punktu widzenia człowieka XX wieku - jego historia obfituje we fragmenty analizy psychologicznej - potrafi on empatycznie wczuwać się w przeżycia zarówno Cerbera, jak i Heraklesa:

Na podobieństwo lawiny spadły na niego dźwięki, kształty i zapachy. Świat jawił mu się w barwach wściekle intensywnych jak płótna fowistów: trawa była płomienna, drzewa cynobrowe, wapienne skały fioletowoczarne, niebo zielone [to o Cerberze; Pies infernalny, s. 21-22].

Heraklesa poniósł głos Cerbera jak potężna fala oceanu. Słuchał. Miał ochotę zawyć razem z nim, ale wiedział, że się skompromituje, bo nie wydobędzie z gardła takiej dumy i rozpaczy" [to o Heraklesie; tamże, s. 23].

Narrator z wielkim pietyzmem i dbałością o formę (niezwykłe porównania, metafory), ze znawstwem sztuki współczesnej prowadzi swoją opowieść. Jesteśmy świadkami zadziwiających perypetii: podczas wędrówki Herakles i Cerber przechodzą metamorfozę - pachnący „krwią, skórą i nawałnicą" (Pies infernalny, s. 22) heros zaczyna mentorskim tonem opowiadać strażnikowi królestwa zmarłych o koniczynie, fotosyntezie i Kancie - staje się nauczycielem, a Cerber nie jest już psem infernalnym, bestią, a kundlem, „postrachem targów warzywnych” i ulubieńcem dzieci (tamże, s. 26). Obaj na końcu chcą założyć cyrk. Kiedy już historia zmierza ku rozwiązaniu, Herakles niespodziewanie niszczy zadzierzgnięte więzy - zabija Cerbera. Ostatnie słowa: „Na wieki pozostaje bez odpowiedzi dręczące pytanie, jak mógł Herakles wpychać w głąb ciemnego otworu ten mokry, brudny worek pełen bezradnych wrzasków i skowytu zawiedzionej miłości” (tamże, s. 27).

Kluczem do zrozumienia tego opowiadania-apokryfu jest ciągle przywoływany język - słowo. Herbert posługuje się na przemian stylami: naukowym, literackim, potocznym, wtrąceniami z niemieckiego, łaciny, stylizując swoją wypowiedź na dramat czy powieść przygodową: „W Mykenach stanęli wieczorem” (tamże, s. 26). Bawi się, opowiadając tę historię - a może właśnie naśladuje postmodernistyczne igranie $\mathrm{z}$ konwencjami. Jednak historia Cerbera 
i Heraklesa, którzy wędrując do króla Eurysteusza, przyjmują różne role: jeńca, błazna, psa, przyjaciela, kończy się tragedią. Bo w świecie, w którym nie ma rozpoznania ról, nie ma też tożsamości, nie ma sensu - wszystko jest możliwe, wszystko jest równouprawnione: dramat i komedia, śmiech i łzy. Wbrew pozorom taki świat nie jest światem wolności, a zniewolenia, nie światem tolerancji, a zbrodni. Przez użycie kostiumu antycznego autor uniknął natrętnego moralizatorstwa, uczynił swoją historię czytelną dla tych, do których mówił - do ludzi wykształconych, bo Herbert nie jest utylitarny - to poeta kultury, kierujący swoje słowa do elit intelektualnych. Wbrew pozorom nie ma nic bardziej ocalającego, jak odkrywanie prawdy, że zrównujący wszystko utylitaryzm tak naprawdę prowadzi do klęski.

$\mathrm{Na}$ koniec tej niepełnej, wybiórczej, fragmentarycznej analizy mitologii Herberta spróbujmy się przyjrzeć tekstowi poświęconemu Prometeuszowi. W Starym Prometeuszu postać zbuntowanego przeciw tyranii tytana traci swój tragiczny wymiar. Mocarz doczekał się wreszcie pogodnej starości. „Pisze pamiętniki. Próbuje w nich wyjaśnić miejsce bohatera w systemie konieczności, pogodzić sprzeczne ze sobą pojęcia bytu i losu”. Zajmuje się zatem jałowymi dywagacjami bez konsekwencji. „Ogień buzuje wesoło na kominku, w kuchni krząta się żona - egzaltowana dziewczyna, która nie mogła urodzić mu syna, ale pociesza się, że i tak przejdzie do historii”. Najbliższymi przyjaciółmi buntownika stali się obecnie „miejscowy proboszcz i aptekarz”. Dokonuje się całkowita deheroizacja bohatera, który uwierzył, że kompromis z tyranem jest możliwy właśnie dlatego, że bunt okazał się jałowy. Symbolem tej jałowości staje się wypchany orzeł i list dziękczynny tyrana Kaukazu. Stary Prometeusz to postać skarlała, zmęczona, wypalona, to ktoś, kto zrozumiał, że sprzeciw wobec tyranii był tylko repetycją tego samego procesu ustanawiania i wzmacniania statusu tyranii. Utwór kończy gorzka pointa, którą jest śmiech bohatera: „jego jedyny sposób wyrażenia niezgody na świat” (Stary Prometeusz, s. 87). Utwór dotyka "problemu współczesnego nihilizmu”"19.

19 Tomasz Garbol, Dlaczego klasyk? O problemie klasycyzmu poezji Zbigniewa Herberta, „Roczniki Humanistyczne” 1999, z. 1, s. 227. 
Stary Prometeusz bardzo przypomina $\mathrm{z}$ ducha i intencji słynny apokryf Franza Kafki zatytułowany Prometeusz:

Cztery legendy mówią o Prometeuszu: wedle pierwszej został przykuty do skały na Kaukazie, ponieważ zdradził bogów dla ludzi i bogowie wysłali orły, które żarły jego wciąż odrastająca wątrobę.

Według drugiej Prometeusz z bólu od uderzeń dzioba wciskał się coraz głębiej w skałę, aż się z nią zespolił.

Wedle trzeciej jego zdrada poszła w ciągu tysiącleci w niepamięć, zapomnieli bogowie, orly, on sam.

Wedle czwartej miano już dosyć tego, który stracił rację istnienia. Znużyli się bogowie, znużyły się orły, zamknęła się w znużeniu rana. Pozostały tylko nieodgadnione góry skalne. Podanie usiłuje dociec tego, co niedocieczone. A że bierze początek z głębi prawdy, musi znaleźć swój kres w niedocieczonym ${ }^{20}$.

Agata Bielik-Robson komentuje tę kafkowską glosę w następujący sposób:

Po latach pełnej tragicznych napieć repetycji tego samego aktu zemsty na dumnej jednostce - kiedy to orzeł co dzień z takim samym zapałem wyszarpywał wątrobę bohatera przykutego do skał Kaukazu, równie gorliwie odrastającą - nagle, jakby w uświadomieniu sobie bezsensu całej tej szamotaniny, ruch na mitycznej scenie wygasa: Die Götter würden müde, die Adler würden müde, die Wunde schloss sich müde... Znużenie, zmęczenie, wyczerpanie, odczarowanie kończą sprawę, która spontanicznie wygasa. To, co pozostaje, jest - jak tajemniczo sugeruje Kafka - sama skała. Skała, kamienne dno bytu zredukowanego do absolutnej literalności. W stanie destytucji podmiot dogorywa wśród postsymbolicznych i posttragicznych skał, na pustyni bez-sensu, gdzie żadna fantazja, żadne wyobrażone nie dodaje nic do tego, co tylko jest: to Ziemia jałowa Eliota, gdzie „słońce zabija, martwe drzewo nie daje cienia, ulgi świerszcze, a suchy kamień szmeru wody"21.

${ }^{20}$ Franz Kafka, Prometeusz, w: Nowele i miniatury, przeł. Roman Karst, Alfred Kowalkowski, Warszawa 1961, s. 370.

${ }^{21}$ Agata Bielik-Robson, «Na pustyni». Kryptoteologie późnej nowoczesności, Kraków 2008, s. 253-254. 
W jednym z wywiadów Herbert głosem nabrzmiałym emocjami wyznawał:

Moją ambicją było, nie wiem czy udało mi się to zrealizować, nie adresowanie do jakiejś grupy ludzi wykształconych, tylko zbudowanie czegoś, co bym nazwał uniwersalnym wzruszeniem, co nie jest tylko moim doświadczeniem, ale może być przekazywalne. Więc jak to zrobić? Nie lubię bardzo takiej liryki bezpośredniej... że słoneczko zachodzi, smutno na duszy, ukochana daleko, prawda, bo to też są pewne uniwersalne... Więc chciałem, usiłowałem zrobić coś, co jest, coś, co może być udziałem różnych ludzi... I właśnie to jest sięganie do tych mitów ${ }^{22}$.

Mity stanowiły dla Herberta jedynie kanwę, na której snuł własne refleksje. To dzięki ich interioryzacji i niezwykle przemyślanej i precyzyjnej kompozycji, w którą zostały wbudowane, poeta potrafił dotrzeć do skrywanej i zniekształcanej w historii prawdy o człowieku. Wystrzegał się przy tym patosu i sentymentalizmu. Wprowadzając do swojego poetyckiego laboratorium antyczną mitologię, nie robił tego na modłę neoklasycystyczną. Zdawał sobie sprawę, że taka poezja i taki humanizm nie ocalają. Prezentował zatem mitologię językiem współczesnym, który dzięki niepowtarzalnemu stylowi i charakterystycznej Herbertowskiej frazie uniwersalizował doświadczenia i losy bohaterów, stając się tym samym najlepszym sprawdzianem aktualności przesłania mitów. Dokonując ich reinterpretacji, Herbert stawiał wiele pytań dotyczących kondycji współczesnego człowieka, którego przepełniony banalnością i charakteryzujący się ucieczką od ważkich, fundamentalnych pytań los stawał się dziełem przypadku. Niejednokrotnie świat współczesny jawił się poecie jako przestrzeń pozbawiona harmonii, w której niszczone były bliskie mu wartości.

Tym mocniej czuł potrzebę rewitalizowania antycznej mitologii, aby w nowy sposób mówić o starych jak świat sprawach. Mit, jak i rozliczne epizody zaczerpnięte ze skarbca tradycji śródziemnomorskiej,

${ }^{22}$ Piotr Załuski (reż.) (2005-006), Zbigniew Herbert - fresk w kościele (cz. 2). Film dostępny w Internecie: https://youtu.be/KKeszFrH1-Q?t=3m44s [dostęp: 26.06.2015 r.] 
stały się pod jego piórem eliotowskim „obiektywnym korelatem”. Jak pisał autor Wydrążonych ludzi:

Jedyną drogą do wyrażenia emocji w formie sztuki jest odnalezienie „obiektywnego korelatu"; innymi słowy: zespołu przedmiotów, sytuacji, łańcucha wydarzeń, które winny być formułą tej konkretnej emocji, tak, że gdy zewnętrzne fakty, które muszą ostatecznie prowadzić do zmysłowego doświadczenia, są dane, emocja jest natychmiast przywoływana ${ }^{23}$.

\section{Summary \\ The Unappreciated Mythology of the Unappreciated. Reflections on Zbigniew Herbert's Król Mrówek or a Tragic Attempt to Tame the Cruelty of Gods}

The article sketchily surveys Zbigniew Herbert's mythological prose texts from Król Mrówek, which remained unpublished during his lifetime. A suite of analytical and interpretive considerations intends to present Herbert as an author who took up the task of investigating the consistency of the Mediterranean myth. The article applies twentieth-century mythology studies tools to situate Herbert's book within literary tradition. In his apocrypha Herbert subjects mythological tradition to a renarration; he shows appreciation for characters traditionally devoid of the grace to speak and reinstates their hitherto deformed human faces. Simultaneously, Herbert undermines the inevitability, necessity, and permanence of the verdicts of the fate which, in traditionally narrated mythology, stands as the final instance bringing back the cosmic order.

Jakub Andrzej Jurkowski (Uniwersytet Kardynała Stefana Wyszyńskiego) absolwent filologii polskiej i filologii klasycznej, doktorant na Wydziale Nauk Humanistycznych UKSW (temat rozprawy: „Po co klasycyzm? Rekonstrukcja wizji cywilizacji łacińskiej w eseistyce polskiej XX wieku”).

\footnotetext{
${ }^{23}$ "The only way of expressing emotion in the form of art is by finding an 'objective correlative'; in other words, a set of objects, a situation, a chain of events which shall be the formula of that particular emotion; such that when the external facts, which must terminate in sensory experience, are given, the emotion is immediately evoked" (T.S. Eliot, The Sacred Wood. Essays on Poetry and Criticism, London 1957, s. 100; tłum. J. Jurkowski).
} 